\title{
TITLE:
}

\section{A Harmonic Calculus on the Sierpinski Spaces(Abstract_要旨)}

AUTHOR(S):

Kigami, Jun

CITATION:

Kigami, Jun. A Harmonic Calculus on the Sierpinski Spaces. 京都大学, 1988, 理学博士

ISSUE DATE:

1988-03-23

URL:

http://hdl.handle.net/2433/86391

RIGHT: 


\section{【56 】}

氏 名木尗淳

学位の種類理学 博士

学位記番号 理 博 第 1089 号

学位授与の日付 昭 和 63 年 3 月 23 日

学位授与の要件 学 位 規 則 第 5 条第 1 項該 当

研究科・専攻 理学研究科 数学専攻

学位論文題目 A Harmonic Calculus on the Sierpinski Spaces

(シルピンスキー空間上の調和カルキュラス)

論文調査委員教 授

\section{論 文 内容 の 要 旨}

申請者の論文はフラクタルの一種であるシルピンスキーガスケットを一般化したシルピンスキー空間上 での調和関数，ラプラス作用素及びをれを用いたポアッンン方程式の解法を述べている。

シルピンスキーガスケットは正三角形から，その 4 分の 1 の正三角形を上下逆にしてはじめの正三角か らとり，残った 3 つの正三角形から同じ操作で更に 4 分の 1 になった正三角形を奴くいう操作を無限に つづけた結果得られる閉集合であるが，これは 2 次元空間での 2-単体からっくった一つの閉集合と見ら れる。このように考えると $\mathrm{N}$-単体から同様のあのが得られると同時に $\mathrm{N}=1$ の場合には，一つの区間が そのように構成できる。そこでこのようなあのをシルピンスキー空間とよぶことにする。

$\mathrm{N}=1$ の場合には，ラプラス作用素は通常の 2 階差分となるが，このとき，そのポアッンン方程式のデ イリクレ問題については, 畑と山口のマルチグリッド差分という方法が，この問題の解に新しい解釈を与 えていた。そこで申請者は，上に述べたシルピンスキーガスケットは，通常の区間の概念を拡張したもの に過ぎないという認識にもとづき，通常の微分が定義できないような一般のシルピンスキー空間にもこの 考えを拡張することに成功したのである。マルチグリッド差分は，微分の代用として，無限個の差分方程 式をつぎつぎと細くなるメッシュに対して同時に考えることであるが，シルピンスキーガスケットの例を 見てあ, その差分法を考察することは簡単ではない。申請者は, ガスケットの有理点に 2 種類あり, 内点 にあたるあのとして，各段階で 4 つの近傍ノードをあつあのと，2つの近傍ノードしかないあの（境界 点）を区別し，この内点に対して，通常の中心差分に似た差分法を考案し，これを無限個用いることによ り, シルピンスキー空間上の調和関数の概念に到達したあのである。

この調和関数を用いて，区分的調和関数による連続関数の展開を用いることによってラプラス作用素を 定義し, しかる後, ポアッンン方程式のデイリクレ問題の解を区間の場合と同様な方法によって与えた。 これは, 具体的な計算法をむ与えるものである。申請者は, 更に進んでこの空間上の関数について，境界 上の法線微分にあたる量む定義し，空間上の関数のラプラシアンとこの量の関係である Gauss-Green の 
定理が成立する条件と定理の証明とを与えている。これを用いることによりノイマン境界值問題も解ける こととなる。要約すれば，解のなめらかさを除いて，ほとんどすべての二階楕円型作用素の性質をすつ， ラプラス作用素をこの複雑な空間上に定義し証明したことになる。参考論文 1 は力オス的力学系における インターミッテンシーの研究であり，2 は, 1 次元力学系での例としての個体群のダイナミックスにおけ るポピュレーションフラッシュのおこることの予告と力学系としての性質の関連性を述べている。3はフ ラクタルの生成に関する独自の原理と関数の本質的特異点および自然境界との関連を解明した。

\section{論 文 審 查の結果の 要旨}

申請者の論文はシルピンスキー空間とよばれる閉集合の上で, 調和関数, ラプラス作用素等を定義し, 更にこのラプラシアンによるポアッソン方程式の解の存在, 一意性, これを解くアルゴリスムをデイリク レ境界条件, ノイマン境界条件のもとで示したものである。

近年, 物理学をはじめとする自然科学の諸分野でフラクタルとよばれる複雑な構造と集合が, たとえば 不純物をいたるところに含む材料等のモデルとして考えられるようになって来た。特にシルピンスキー空 間の一例であるシルピンスキーガスケットはそのようにしばしば固体物理学者によって用いられて来てい る。

そこで,このような集合上の微積分とは如何なるすのかということが数学者に対して問いかけられてい るが，それに対する一つの答が申請者の論文である。上の空間は特別な場合として単なる区間を含むが, この場合には畑, 山口の仕事が普通の微分法の別解釈としてマルチグリット差分法による定式化を与えて いる。申請者はこれを一般のシルピンスキー空間上に独特の洞察により拡張したあのであり, 学問上きわ めて重要な考察である。

参考論文 3 篇はいづれもカオス，フラクタルについての独創的な研究である。

以上によって,この論文は理学博士の学位論文しての価值があると認めた。

なお主論文及び参考論文に報告されている研究業績を中心とし，これを関連した分野について試問した 結果合格と認めた。 